\title{
4 \\ Piloting the experimental ZEESM megaproject: Performing the future in the Oecusse-Ambeno enclave ${ }^{1}$
}

\section{Laura S. Meitzner Yoder}

'So, what did you think of the inauguration?' I asked my young Oecusse friend as we joined hundreds of people walking home from Lifau. We were leaving the site of the district-wide Catholic mass and the dedication of a sizable ship monument depicting the disembarkation of Portuguese Dominicans and their first contact with several Oecusse men. It was 27 November 2015, the culmination of the week-long festivities of what the national government of Timor-Leste was calling a 'celebration of the affirmation of Timorese identity' (GoTL 2015). The purported reason for the event was the (approximately) 500th anniversary of the arrival of Portuguese clerics to Oecusse's shores, co-celebrated with the 40th anniversary of a Timor-Leste 1975 declaration of independence. This landing was celebrated because it symbolised the start of Portuguese presence on the island of Timor, which developed into a colonial presence that lasted until Portugal abandoned the region due to civil chaos

1 This paper draws on ZEESM publicity and public meetings from 2013 onward and focuses on events surrounding the celebration in Oecusse in late November 2015, as well as near-annual visits from 2011 to 2017. I conducted initial ethnographic fieldwork in Timor in 2001, and was based in Oecusse from 2002 to 2004. 
at home. The Oecusse-Ambeno region had served as the first colonial capital from 1701 to 1769 . It retained its ties to Portuguese rule even when the surrounding territories came under Dutch control from the eighteenth century, leaving Oecusse an enclave of the Portuguese territory that eventually became what is today the majority Catholic nation of Timor-Leste. The fledgling nation was under military occupation by its Indonesian neighbour from 1975 until 1999. Following a brief period under United Nations transitional administration, Timor-Leste became fully self-governing in 2002 .

The previous week had featured multiple nights of international musical entertainment on a large stage, a local products fair, mass Catholic weddings and confirmations, and popular events like motocross competitions. This evening's festivities featured official actions (signing plaques, unveiling statues, short speeches and blessing the monument with holy water) by a range of visiting dignitaries from Dili, church leaders and envoys from Portuguese-speaking countries who had spent the previous hours - or days - ferried from one high-level event to another in VIP cars. An impressive fireworks display - launched from the beach and two boats some distance from the shore, and featuring a small drone dramatically hovering unscathed among the aerial explosions - had capped off the celebration. The volume of visitors and of public entertainment over the past four days exceeded the sum total of everything the largely agrarian Oecusse district had seen in the previous decade combined.

My friend was silent for a while, and then she responded:

To be honest, it made me angry. The celebration was in Oecusse, but it was not about Oecusse. We, and our Oecusse cultural traditions, barely got mentioned. It was about Portugal, and run by Dili. All those guests did not even learn about our home; we didn't even get to see them. And there should have been takanab [one highly appreciated interactive form of Oecusse ritual speech that usually serves to open events] at the monument's inauguration.

This response illustrates some of the complexities facing the nascent government of the Special Administrative Region of the OecusseAmbeno enclave (RAEOA [Regiāo Administrativa Especial de Oé-CusseAmbeno]). In addition to marking 500 years of Portuguese contact and 40 years since declaration of Timor-Leste's independence, the November 2015 celebration was simultaneously the major public 'opening event' of the Special Economic Zone of Social Market Economy of Timor-Leste 
(ZEESM [Zonas Especiais de Economia Social de Mercado de Timor-Leste]), which came into being in 2014 and since 2015 has been in effect a radically decentralised government project. ZEESM exhibits a distinctly and deliberately futuristic vision, and the specific ways in which this vision is being expressed in Oecusse will have significant impacts on the current and near-future lives and livelihoods of Oecusse residents (Meitzner Yoder 2015). This chapter briefly explains the genesis of the ZEESM initiative and its overarching vision for transforming Oecusse realities. It then examines multiple actors' perspectives on the relationships between the past and the future, how the approach of 'investment enclaving' is being deployed in ZEESM as a pilot project, and the performative aspects of this initiative.

\section{'Creating the future': From the National Development Plan to a regional government}

The genesis of ZEESM lies in the 2011-2030 national strategic development plan; thus, the overarching vision for how this project transforms Oecusse bears implications for the rest of Timor-Leste. This document names the creation of special economic zones (SEZs) as central in the economic plan (Republica Democratica de Timor-Leste 2011). The plan lists six 'National Strategic Zones' that span the territory, and the Oecusse-Ambeno SEZ is the first to be implemented. In government speeches and documents, the creation of the Oecusse SEZ is frequently cited to be in line with the national development plan, billing Oecusse as a 'pilot project' that will set an example and a new path for the rest of the nation. A budget report and request to Parliament states that the new ZEESM concept will 'challenge the development paradigm and model in Timor-Leste and will start first from Oecusse-Ambeno' (RAEOA and ZEESM 2015: 2 [my translation]). The Oecusse-Ambeno zone is envisioned to introduce a multiplicity of novel changes:

There are a variety of potential sectors that will be developed such as international trade, CIQS [Customs, Immigration, Quarantine, and Security], development at selected junction points, new plantation areas and new livestock extension services, new fish processing industries and a new creative industry, as well as new tourist sites. (Republica Democratica de Timor-Leste 2011: 116) 
Tourism gets the most attention for economic development in the enclave (ibid.: 96). In the case of Oecusse, the plan to develop 'a special administrative policy and economic regime' for the district fulfils a 2002 constitutional mandate for attention to the unique situation of the enclave. In 2013, the Council of Ministers and Prime Minister Xanana Gusmão appointed former prime minister Mari Alkatiri to an undefined term of service in order to oversee the development of the Oecusse-Ambeno SEZ. Alkatiri began by enlisting the aid of international technicians and consultants, and seeking inroads with potential investors. From these practices emerged an ultramodern vision of Oecusse's future, in which foreign investment in as-yet-unidentified sectors would transform the largely agrarian district into an urban industrial hub. The initial stage centres on a massive revamping of the tiny downtown of the enclave's capital, Pante Makassar, replacing simple, functional existing buildings with architectural novelties and adding major infrastructure projects deemed foundational and necessary to attract foreign visitors and investors to the district. In May 2013, Alkatiri went on a publicity visit to Oecusse in which he unveiled this plan fully formed in a series of speeches and a public slide presentation, informing rather than consulting the local population of this futuristic vision for their district. From 2014 to early 2017, under the heading 'Creating the Future', the ZEESM website showed the same sketches of the projects currently underway that were shown to the population in public meetings since 2013 and still prominently displayed on Oecusse billboards in early $2018 .^{2}$ The widely publicised price tag for the entire ZEESM endeavour was estimated to be US\$4.11 billion, with one-third coming (mostly at the outset) from public funding. From 2014 to 2017, ZEESM received US\$544 million from the national government (La'o Hamutuk 2018). As discussed elsewhere in this volume, at present over 90 per cent of the national state budget comes from oil and gas revenues that became accessible within the past decade, so, in a real sense, the ZEESM endeavour is made possible by this petroleum income.

2 The ZEESM projects listed include only planned buildings and capital investments: the international airport; the Hotel ZEESM Timor-Leste; a tourism and cultural information centre; a multi-storey RAEOA administrative building; the expansive ZEESM villa and residential complex; a seafront park with free wi-fi; a ferry boat; a power station; a garden and sports park; a 200-metre dam and associated irrigation network; 50 kilometres of coastal and lowland urban roads, especially from Oecusse's eastern Indonesian border to the Lifau Monument; a 380-metre bridge along the coastal road; and an amphitheatre-style Lifau Monument 'for the celebration of the 500th anniversary of the arrival of Portuguese navigators and missionaries in Lifau-Oecusse, a fact that marks the beginning of construction of the new identity of Timor Leste' (ZEESM 2016). 
The declaration of Oecusse as an SEZ brought about a major change in its governance structure. To enable the project, the enclave district was legally named a Special Economic Zone of Social Market Economy (ZEESM) in mid-2014. The RAEOA was created and formally implemented by law in January 2015. The RAEOA is presently tasked with implementing the ZEESM project; government letterhead lists both names and logos, indicating that the Regional Authority (the district's government) and the SEZ (an economic development project) are coterminous (RAEOA and ZEESM 2015). All power over governance and budget for the district (except the usual national matters of external defence, currency policy, etc.) were vested in the Regional Authority, and Alkatiri has a skeleton crew of seven Oecusse-based regional secretaries of various sectors. As the centrally appointed head of the ZEESM 'pilot project' as well as president of the Regional Authority, ${ }^{3}$ Alkatiri oversees the district development plan to align all public spending - including schoolteachers' salaries, water supply, and health promotion and care facilities - with construction for the substantial public infrastructure projects underway. Importantly, civil servants in social services and public offices in Oecusse now report to the Regional Authority in Oecusse instead of to the national capital's Dili offices of their various sectors. The RAEOA-ZEESM entity was tasked with executing the November 2015 celebration as one of its first duties, simultaneously showcasing its plans and construction progress to date.

\section{The beginning is the future; the future begins in the past}

Nationwide, Oecusse is known primarily for being the place where the Portuguese first landed and where the Catholic Church first entered the island, and is often named as one of Timor-Leste's 'most traditional' districts (ZEESM 2013: 51). The enclave's historical importance is a source of great pride to Oecusse people, and modern political figures can reliably prompt an Oecusse crowd to cheer enthusiastically by repeating the refrain, 'Without Oecusse, there would be no Timor-Leste!' At the November 2015 celebration, as in ZEESM foundational documents,

3 As a result of mid-2017 elections, Alkatiri once again took the national position of prime minister; he left that post after the May 2018 elections. However, in 2017, he did not relinquish his role as Oecusse's president of the RAEOA, but instead appointed an interim president from among the regional secretaries. 
then president Taur Matan Ruak extended the importance of these events to declare that Oecusse-Ambeno was where the groundwork for the modern nation-state of Timor-Leste was laid, and that the arrival of the Catholic Church and the Portuguese were foundational to the East Timorese as a people. The president's media report stated:

In his speech, the Head of State designated Lifau as the place of birth and development of the Timorese identity, 'It was here that our relationship with the Portuguese people began and where it blossomed, thus shaping our identity - an identity built on two important pillars: the Portuguese language and Catholicism'.

H.E. the President congratulated the people of Oecusse, as well as all Timorese, the Portuguese people and the peoples of all other CPLP [Portuguese-speaking] countries, and reminded them that Timor-Leste was born in Lifau and developed in Oecusse. The unveiling ceremony ended with a photo session with CPLP dignitaries and the bishops. (Presidência da República de Timor-Leste 2015b)

Capitalising on popular conceptions of Oecusse as 'the place where it all began', the ubiquitous tagline of the ZEESM project, featured on the letterhead logo as well as on hundreds of signs and banners throughout Oecusse, is $O$ inicio é o futuro ('The beginning is the future'). Timorese political figures have drawn rhetorical parallels between the importance of Oecusse in national political history and its anticipated importance in Timor's economic future; the place credited with getting Timor-Leste started will now be the model for a new program of economic development and a new era of prosperity. The ZEESM website proclaims:

Besides the history of the Timorese nation having started in Oé-Cusse, the fact is that it is one of the poorest regions, with more than $60 \%$ of the population living below the poverty line, was also one of the reasons why it was chosen to start a new future for the country. A future committed to Prosperity, Peace and Performance. (ZEESM 2016)

The future-oriented ZEESM project explicitly aims to be different from the past and to supersede the conditions of the present. Among Oecusse people, as is common throughout Timor and the broader region, the past is not disconnected from the future, but rather interwoven to create a comprehensible whole. The past informs the present (and future), providing a framework within which decisions are made and life makes sense. Writing about Oecusse's Atoni ethnolinguistic group in Indonesian West Timor, Schulte Nordholdt (1971: 61) explains, 'In his [Atoni] 
culture the past is normative and is considered the ideal situation - it cannot but have been better than the present'. The present is a by-product of an idealised past, which focuses less on the colonial connection than on indigenous authorities and polities. Topics under frequent discussion by Ambeno people involve folklore and legends about indigenous inhabitants, early rulers and leading figures.

In the middle of the November 2015 celebration, the local academics' Oecusse-Ambeno Intellectuals' Association presented the preliminary results of their inaugural research, entitled Oral history of the Oe-KusiAmbeno people (later published as Taçain et al. 2016). Alkatiri briefly attended to offer an opening speech with reflections on the conflictual nature of studying history, and joked how different it is from science, which now explains many things that people did not understand in the past. Mentioning that identity is dynamic, he said that he didn't want people to come to Oecusse to see the past, emphatically stating, 'We are missing the future, not the past'. Then, true to the Oecusse and Atoni predilection for history-telling, the research team proceeded to present their distinctly past-centric report. For more than two hours, the research report narrated the development of regionally diverse social structures present in Oecusse-Ambeno, weaving in the legendary indigenous rulers, the political rise and fall of local dynasties and the subsequent creation of sacred and politically important places throughout Oecusse. They explained why this research was their inaugural project: to provide information about the traditional social structure of their own Ambeno people, since within Oecusse there are many differences in perception about history; and to preserve 'for the generations today and in the future' the inherent variability in the data, as people in each region of Oecusse tell history in ways that put themselves in premier positions. Their project was based largely on interviews with 40 older men from various villages who are acknowledged as authoritative on matters of Oecusse-Ambeno history and custom, but the project's stated goal was not to present one standardised narrative, as none is possible. For the local researchers and for their participants, their descriptions acknowledge the past as critically important in giving meaning to and making sense of the present and the future - not as something to be superseded or supplanted by new, modern or scientific understandings of how the world operates. 


\section{Investment enclaving: Pilot projects and the source of future prosperity}

Investment is the quintessential future-oriented activity. It involves present sacrifice for potential future gain, often forgoing some current use in hopes of yielding even more in the time to come. The entire OecusseAmbeno project is predicated on the premise that building infrastructure in Oecusse will enable the realisation of some types of economic development initiatives that will bring outside wealth into the district, which will in turn generate profit and economic growth. The early stages of the project are aimed at providing the basic infrastructure (e.g. roads, electricity, transportation) that the ZEESM leadership believes will enable the district to be sufficiently attractive to foreign investors.

The investment-oriented ZEESM-RAEOA entity - simultaneously infrastructure-building project and local government - complicates the state/corporate divide common in discussions of how global market rise affects the relevance of state governance. Speaking of extractive oil industries in Africa, Ferguson (2005: 378) writes, 'What is noteworthy is the extent to which this economic investment has been concentrated in secured enclaves, often with little or no economic benefit to the wider society'. He continues:

The clearest case of extractive enclaving (and no doubt the most attractive for the foreign investor) is provided by offshore oil extraction, as in Angola, where neither the oil nor most of the money it brings in ever touches Angolan soil. (ibid.: 378 [my emphasis])

He describes a situation in which profits skip among global capitals rather than flowing through national economies, 'noteworthy for their ability to bypass the national-state frame altogether' (ibid.: 379). Oecusse's future wealth - unlike that of the Tasi Mane project described by Bovensiepen in this volume - does not depend on natural resource extraction, but rather on what I will call an intense investment enclaving by the state, and hopedfor foreign business interests in limited, circumscribed areas. In Oecusse, the enclaving of public spending - within Oecusse, disproportionately on coastal megaprojects; and on a national level, disproportionately in the SEZ - does not automatically lead to economic improvement in the whole of Oecusse, nor in the rest of Timor-Leste. And while Ferguson's (2005: 79) corporate extractive enclaves expect to provide all their own 
security, infrastructure and services, the Timorese state's investment enclave is oriented towards providing the basic infrastructure and services deemed essential precursors to attracting foreign investment.

National leaders have raised the matter of inter-district equity, justifying the disproportionate investment in this stage of the ZEESM development and calling upon Oecusse people to invest themselves. While visiting the new power plant in Oecusse, then president Taur Matan Ruak stated:

I ask the people of Oecussi, authorities, scholars, the youth, community leaders, traditional leaders, the population in general, to support the establishment of the ZEEMS [sic]. All other municipalities had to tighten their belts so as to save up for Oecussi. This is a great opportunity for the people of Oecussi. The President asks you to contribute to the success of this project. (Presidência da República de Timor-Leste 2015a)

The former president Ramos Horta reminded the population that infrastructure is the necessary precondition to attract investors, and that the pilot project of ZEESM will be of eventual benefit to the other 12 districts (Matadalan Online 2015). While the present directionality of funding is being channelled from Dili to Oecusse (as expected in this stage of using public funds for major infrastructure projects), there is a clear expectation that this public spending on infrastructure will eventually yield financial gain to the nation as a whole.

The initial public spending on the Oecusse enclave's infrastructure is rarely framed as motivated by altruistic or humanitarian impulses; nor does it express a desire to bring this heretofore neglected district up to the level of other districts. The 2011 National Strategic Plan is explicit about the role of SEZs as central to national economic development strategy. These zones are expected to 'drive domestic development' and 'generat[e] national income' by contributing to the national coffers (Republica Democratica de Timor-Leste 2011: 155). ZEESM documents certainly demonstrate an understanding that the initiative is a novel approach to economic development that aspires to be a 'national model', a 'new paradigm', a 'pilot project' and an 'incubator' for what can be later replicated elsewhere in Timor-Leste (RAEOA and ZEESM 2015). Alkatiri has hailed the project as a 'development laboratory' and as a 'model' (referência) for Timor-Leste (Agência Lusa 2015). 
ZEESM is not only to serve as a pilot for a new national approach to economic growth, but also as a testing ground for new policies, laws and models of governance that may later be extended nationwide. Describing the project plans, Alkatiri noted that Oecusse would have a nationally distinct legal framework: 'The immigration law, labour, fiscal, trades, everything you need, it has to be different than the normal one here in Timor-Leste, to be a bit more attractive for investors' (Gabinete da Ex Primeiru Ministro Dr Mari Alkatiri 2013). In April 2014, the national Council of Ministers approved an accelerated legislative process to permit infrastructure preparations for the November 2015 celebration (Business Timor 2014). One of the pieces of legislation that passed concerned land, which is especially notable as Timor-Leste had yet to develop a comprehensive land policy or associated legislation on a national level until mid-2017, when Timor-Leste promulgated a national land law (Almeida 2016; Batterbury et al. 2015). Section IV, Article 26 of Law No. 3/2014 (published on 18 June 2014) has two clauses regarding land utilisation that focus on the state's right to take land for purposes of development and for investors in economic activity, but no mention is made of local residents' land rights or uses.

Just as not all expenditures are investments, not all pilot projects are built to fly. Pilots that are miniature, contained experiments may not contain the design elements that will enable them to be replicated elsewhere (Billé 2010). Is ZEESM meant to be replicable? This is clearly the stated intent as written in the national strategic development plan. A pilot project involves both connection and uniqueness, linkage and separation. A useful pilot will be conducted in conditions typical enough of the whole so that the results and lessons learned will not be explained away as effects of some anomalous quality of the pilot's context. The pilot project is also an opportunity to test various elements - economic models, policies, novel governance arrangements - in a relatively low-risk setting to deliberately contain failure so that major errors would not have catastrophic effects on the larger enterprise or setting. One very important function of a pilot project is to give rise to lessons that enable the implementer to learn from them and make corrections when expanding out or scaling up. Capturing such lessons learned, however, requires deliberate, dedicated effort by project overseers to document and to evaluate what is done - including naming unsuccessful aspects and identifying how they could be addressed in the future. 
Oecusse's physical separation from other districts is what caused the region to be promised special administrative and economic treatment in Timor-Leste's 2002 constitution; ${ }^{4}$ since 2014, this has taken the form of an explicitly investor-friendly incipient SEZ governed by an unelected regional authority. Since 1999, Oecusse's persistent logistical difficulties in communication with the eastern districts have necessitated some degree of self-governance in the enclave, as land and air access to the eastern districts are scant and transport by sea is erratic due to seasonal conditions and periodic unavailability of the boat service. From this perspective, Oecusse's atypical geographic isolation may have been its comparative advantage as a place to develop and implement untried governance practices for Timor-Leste, including significant upfront spending of public money in an effort to attract foreign investment.

\section{Conclusion: Performing national visions}

How might ZEESM illustrate the future vision of Timor-Leste? In the authors' workshop that gave rise to this book, several participants commented that Oecusse seemed to be serving as a testing ground for a new national vision of economic development embodied in ZEESM. Some initiatives of the international humanitarian and state-building community from the United Nations era treated all of Timor-Leste in this way - as a manageably small and compact entity in which it ought to (and just might) be possible to get everything right, as if histories did not matter and as if states, economies or societies could be built from scratch (Kammen 2009). The ZEESM miniature model for a state vision of prosperity has been enabled by the nation's present oil and gas wealth, even as it purportedly aims to attract a different income stream for the nation. Speaking of ZEESM in Oecusse as a pilot links the outcomes in Oecusse rhetorically to the rest of the nation, even though special legal and administrative regimes entrench the enclave's distinction and isolation. In contrast to the administrative era of the United Nations and international advisers, Oecusse could provide an opportunity for Timorese to develop laws and policies that suit the realities of a largely agrarian but recently urbanising context. On a national level, the president has emphasised the importance of investing in human capital, as it is more certain to provide returns than building infrastructure (Decreto do

4 Section 5, Clause 3, and Section 71, Clause 2, respectively. 
Parlamento Nacional n.o 20/III 2016). Ferguson (2005) reminds us that it is not only possible, but common for hyper-networked fiscal enclaves to look like economic successes while leaving vast tracts of minimally governed hinterlands ignored or out of the picture - a situation that may be of low moral concern to an international offshore expatriate oil investor, but is an integral responsibility of a state apparatus.

There are multiple layers of performance in ZEESM. As a pilot project, many are watching and waiting to see how the district fares as the subject in this experimental economic laboratory. The 'show' must be good enough to impress and subsequently woo potential investors to buy into the company. For ZEESM project managers, part of the performance pressure for the early activities is to demonstrate competence and efficiency in modern governance, employing an ability to accomplish extraordinary transformation in a difficult setting. The November 2015 celebration was a performance of Timorese political visions of national identity for multiple audiences. With Oecusse as the stage, ZEESM is simultaneously playing the roles of building project contractor and regional government, performing a new iteration of the state vision of development, political consensus and a prosperous future.

\section{References}

Agência Lusa (2015) Projecto de OeCusse deve ser referência para todo o país - Mari Alkatiri [OeCusse project should be a model for the whole country - Mari Alkatiri]. Available at: portocanal.sapo.pt/noticia/50095/.

Almeida, B. (2016) Land tenure legislation in Timor-Leste, Leiden: Universiteit Leiden Faculty of Law and The Asia Foundation. Available at: asiafoundation. org/wp-content/uploads/2016/04/Land-Tenure_TL_EN.pdf.

Batterbury, S. P. J., Palmer, L. R., Reuter, T. R., de Calvalho, D. do A., Kehi, B. and Cullen, A. (2015) 'Land access and livelihoods in post-conflict TimorLeste: no magic bullets', International Journal of the Commons, vol. 9, no. 2, pp. 1-29. doi.org/10.18352/ijc.514.

Billé, R. (2010) 'Action without change? On the use and usefulness of pilot experiments in environmental management', S.A.P.I.E.N.S. [Online] vol. 3, no. 1. Available at: journals.openedition.org/sapiens/979. 
Business Timor (2014) 'Preparasaun Tinan 500 Portugal tama Timor, KM Hasai Pontu 12 ba ZEEMS' [In preparation for 500 years of Portugal's entry to Timor, Council of Ministers gives 12 points about ZEESM], Jornal Bisnis Timor, 28 April. Available at: www.jornalbisnistimor.com/notisia/ politika/1990-preparasaun-tinan-500-portugal-tama-timor-km-hasai-pontu12-ba-zeems.

Decreto do Parlamento Nacional n.o 20/III, Orçamento Geral do Estado para (2016) Mensagem ao Parlamento Nacional do Presidente da República Democrática de Timor-Leste: Taur Matan Ruak na Promulgação do Orçamento Geral do Estado para 2016 [Message to national Parliament from the President of the Democratic Republic of Timor-Leste: Taur Matan Ruak on the Promulgation of the General State Budget for 2016].

Ferguson, J. (2005) 'Seeing like an oil company: space, security, and global capital in neoliberal Africa', American Anthropologist, vol. 107, no. 3, pp. 377-382. doi.org/10.1525/aa.2005.107.3.377.

Gabinete da Ex Primeiru Ministro Dr Mari Alkatiri (2013) Special zones of social market economy: Pilot location Oecusse. Available at: www.zeesm.com/zeesmofficial-video/ (site discontinued) [accessed 11 January 2015].

GoTL (Government of Timor-Leste) (2015) 500th anniversary of the Affirmation of the Timorese Identity. Available at: timor-leste.gov.tl/?p=13165\&lang=en.

Kammen, D. (2009) 'Fragments of utopia: Popular yearnings in East Timor', Journal of Southeast Asian Studies, vol. 40, no. 2, pp. 385-408. doi.org/ $10.1017 /$ S0022463409000216.

La'o Hamutuk (2018) Rights and sustainability in Timor-Leste's development, La'o Hamutuk - The Timor-Leste Institute for Development Monitoring and Analysis, Dili. Available at: www.laohamutuk.org/econ/briefing/RightSustain CurrentEn.pps [accessed 24 February 2018].

Matadalan Online (2015) 'Projetu ZEEMS La Deskrimina Munisípiu 12' [ZEESM Project does not discriminate against 12 municipalities], Matadalan Online, 22 August. Available at: matadalan.com/projetu-zeems-la-desk rimina-munisipiu-12/ (site discontinued).

Meitzner Yoder, L. S. (2015) 'The development eraser: Fantastical schemes, aspirational distractions and high modern mega-events in the Oecusse enclave, Timor-Leste', Journal of Political Ecology, vol. 22, pp. 299-321. Available at: jpe.library.arizona.edu/volume_22/Yoder2015.pdf. doi.org/10.2458/v22i1. 21110. 
Presidência da República de Timor-Leste (2015a) H.E. the President of the Republic TMR Asks the Atoni People to Support ZEESM. Pante Makassar: Ambeno. Available at: presidenciarepublica.tl/2015/12/01/h-e-the-president-of-therepublic-tmr-asks-the-atoni-people-to-support-zeesm/?lang=en.

Presidência da República de Timor-Leste (2015b) H.E. the President of the Republic, Taur Matan Ruak, Unveils Monument in Lifau. Dili. Available at: presidenciarepublica.tl/2015/12/03/h-e-the-president-of-the-republic-taurmatan-ruak-unveils-monument-in-lifau/?lang=en.

RAEOA and ZEESM (2015) Audiência conjunta da Comissáo C Parlamento Nacional [Joint Hearing of Commission C of National Parliament], OGE RAEOA e ZEESM TL 2016.

Republica Democratica de Timor-Leste (2011) Timor-Leste strategic development plan 2011-2030, Dili: RDTL. Available at: www.laohamutuk.org/econ/ SDP/2011/Timor-Leste-Strategic-Plan-2011-20301.pdf.

Schulte Nordholt, H. G. ([1966] 1971) The political system of the Atoni of Timor, Verhandelingen van Het Koninklijk Instituut voor Taal-, Land-, en Volkenkunde, 60, The Hague: Martinus Nijhoff. doi.org/10.1017/S00 $41977 X 00110419$.

Taçain, J., Bacun, P., and de Almeida, N. C. (2016) Kultura no Natureza Ema Atoni-Oékussi-Ambeno [Culture and Nature of Atoni-Oékussi-Ambeno People], Dili, Timor-Leste: UNTL.

ZEESM (2013) Projecto piloto distrito Oecusse [First steps towards a new Oecusse].

ZEESM (2016) Home page. Available at: zeesm.com/oe-cusse-ambeno/ (site discontinued) [accessed 30 January 2016]. 
This text is taken from The Promise of Prosperity: Visions of the Future in Timor-Leste, edited by Judith Bovensiepen, published 2018 by ANU Press, The Australian National University, Canberra, Australia.

doi.org/10.22459/PP.2018.04 